\title{
PROSES TERJADINYA SUATU KARYA SENI
}

\author{
Eka Titi Andaryani \\ FIP Universitas Negeri Semarang \\ E-mail: ekatitiandaryani@gmail.unnes.ac.id
}

\begin{abstract}
Abstrak
Seni adalah keindahan yang tertuang di dalam sebuah karya. Karya seni muncul tidak dengan serat-merta. Artinya, ada beberapa tahapan atau proses yang melingkupi kemunculan suatu karaya seni. Peran manusia (seniman) sangat menentukan proses terjadinya karya seni. Proses karya seni ini dapat diibaratkat sama dengan proses kemunculannya seorang manusia di bumi ini. Tahapantahapan proses karya seni memberikan sejauh mana karya seni itu muncul sebagai realitas yang estetis. Tahapan-tahapan tersebut, antara lain: kehamilan, pertumbuhan, kemasakan, sketsa, dan pembentukan. Kelima tahapan proses terjadinya karya seni tersebut membentuk suatu kesatuan kreativitas manusia (seniman).
\end{abstract}

Kata kunci: seniman, seni, fantasi, cipta, estetis

\section{THE ART-MAKING PROCESS}

\begin{abstract}
Art is beauty which is expressed in a kind of work of art. It does not suddenly appear, meaning that there must be some stages or processes along the emergence of an art work. The artist's role helps determine the process. It is like the emergence of human beings on earth. The stages and processes tell many things about how far the work appears as a kind of aesthetic reality. Those stages are pregnancy, growth, maturity, sketches, and formation. Those five stages form human beings' creativities (artist).
\end{abstract}

Keywords: artist, art fantasy, creation, aesthetic

\section{PENDAHULUAN}

Tulisan ini mencoba mengantarkan masuk ke alam renungan, membayangkan proses terjadinya suatu karya seni. Perlu kiranya diperhatikan apa yang sebenarnya mendorong manusia dengan sendirinya ke permukaan kesadaran dalam proses penciptaan seni ini, agar demikian manusia bisa menangkap peristiwa penciptaan seni ini seperti pengalaman seorang seniman, yaitu dengan bantuan dari dalam dan arah bantuan itu, sehingga karya seni itu selesai diciptakan. Sejauh itu pula manusia 
selalu boleh mengharapkan bantuan dari dalam tersebut pada saat-saat gejolak hati manusia muncul. Manusia harus bisa menangkap proses penciptaan seni itu seperti pengalaman-pengalaman yang disampaikan kepada orang lain, lagi pula telah dijelaskan melalui teori umum tentang pribadi manusia. Bila manusia bisa berhasil, maka dikatakan telah dapat memberikan andil suatu teori penciptaan seni (Saini, 2001:43-45).

Kiranya hal ini akan lebih berharga atau lebih berarti bila dibandingkan dengan sebuah gambar yang indah, apabila kita samakan terjadinya suatu karya seni dengan proses terjadinya seorang manusia, seperti halnya kalau membicarakan mengenai soal mengandung, tumbuh, dan akhirnya lahirnya suatu karya seni. Demikianlah, karya seni harus bisa disamakan dengan psiko-fisiknya organisme (setiap bentuk hidup). Oleh karena itu untuk menerangkan terjadinya proses tersebut, dirasa tidak ada gambaran lain yang lebih pantas dan lebih sesuai dari pada menggambarkan proses terjadinya suatu karya-seni itu seperti proses terjadinya seorang manusia. Apa yang dilakukan dalam bakal terjadinya seorang manusia secara fisik, mula-mula akan dilakukan pula dalam bakal terjadinya karya seni secara fisik. Seniman dalam arti tertentu memiliki kedua nature ini: yaitu perempuan dan laki-laki. Perasaan adalah merupakan prinsip perempuan, perasaan memiliki sifat menerima, ia menerima benih hidup dan menghidupinya hingga menjadi masak. Sebaliknya fantasi adalah merupakan prinsip laki-laki, ia memiliki sifat mencipta, membuahi, mengadakan serta menjadikan bentuk. Di situ fantasi dan perasaan harus berpadu kalau suatu karya seni harus terjadi. "Perasaan atau rasa yang dimaksud bukanlah rasa yang bersifat jasmani, melainkan rasa yang lebih mendalam, yaitu rasa rohani-jasmani” (Driyarkara, 1980:72). Seperti seorang seniman mengalami pola seksual dalam dirinya sendiri, sebegitu kuat dia mengalami itu, dibanding orang lain yang tidak berkarya mencipta di alam ini. Boleh dikata, hampir tidak ada seniman tanpa perkembangan seksual yang kuat. Justru keadaan yang demikian, itulah yang sangat membantu seniman dalam mengembangkan fantasi-perasaan seninya. Demikianlah, seolah-olah terjadi hubungan seksual secara rahasia antara fisik dan psikis. Seperti telah terjadi pembuahan dan itu telah mulai tumbuh berkembang serta berakar 
menjadi janin. Kejadian itu tiada lain adalah merupakan pembeberan diri-sendiri, yang bisa dijadikan dasar pengenalan psiko-fisik pribadi seniman secara netral. "Hanya pikiran yang jernih mampu membuat suatu bahasa yang baik, hanya. pandangan yang jelas mampu menghasilkan suatu gambaran yang baik" (Hartoko, 1993:8). Kalau sekarang terjadinya suatu karya, seni disamakan dengan terjadinya seorang manusia, maka proses selanjutnya perlu kita bedakan tahap demi tahap, seperti: kehamilan, pertumbuhan, kemasakan, sketsa, dan pembentukan.

\section{KARYA SENI: SUATU PROSES MENJADI}

\section{Kehamilan}

Seperti manusia berasal dari satu sel telor yang dibuahi, demikianlah karya seni berkembang dari benih pengalaman yang dibuahi oleh fantasi cipta, yang bisa disebut ide: karya seni. Suatu kesan yang didapat secara langsung atau tidak langsung, yaitu dari lingkup kecil dunianya, yang bisa merubah seniman ke gerak-gerak yang cepat dan hidup, yang merangsang keluar dari keadaannya yang seimbang dan mengundang suatu perasaan yang merangsang kuat dan menegangkan. Seniman yang mengalami keadaan seperti itu merasa kesadarannya menjadi suram. Dia merasa cita-citanya atau keinginannya tak dapat dielakkan lagi, merasa dirinya bersatu erat dengan kesan.

Demikian hamilah fantasi perasaan yang merasa menerima benih hidup, semakin utuh membentuk cita-cita pribadinya dalam proses pertumbuhan serta pengesahan dirinya. Pengalaman pokok, kesan yang merangsang, serta ide kearah fantasi bentuk bersama-sama menuju ke arah penggambaran pribadi seniman.

Dengan kehamilan itu, timbullah rasa ingin yang besar, keinginan untuk meninggikan jiwanya, seperti suatu perbuatan yang estetis, karakteristik. Tetapi bersamaan itu tersembul pula suatu rasa ketidaktenangan yang dapat menghanguskan dan menegangkan hati, yaitu yang ditimbulkan oleh gangguan keseimbangan dalam. Dari kejadian itu semua seniman merasa telah dituntut untuk segera membebaskan dirinya dari kesan hamil itu dengan tindakan atau perbuatan 
mencipta. Dengan demikian, dia menyatukan diri dengan perasaan ingin akan kehamilan itu, dan dia tahu bahwa akan terjadi suatu kelahiran.

Kesan itulah yang mengantarkan seniman kepada ide suatu karya seni. Apakah itu betul diperolehnya secara pasif atau malahan secara kebetulan saja? Tetapi bagaimana pun juga cita-cita itu lebih banyak ada pada seniman, yang menuju ke arah pengembangan diri, artinya untuk menyatakan pribadinya, yang tanpa disadari mendorongnya kesuatu cita-cita yang kompleks serta menekannya kesuatu keinginan fantasi, yang telah dipilihnya sendiri dari sejumlah besar di luar kesan, yang bisa memuaskan cita-cita ekspresinya. Jadi tanpa disadari seniman memilih ide itu sendiri ke dalam karyanya. Tetapi dia mengalami kehamilan itu yang menjadikannya lebih sadar atau kurang sadar mengikuti peraturan dari pada meninggalkan peraturan, mungkin juga itu bisa menjadi suatu inspirasi yang lebih tinggi. Semakin orang tahu dan mengerti dengan jelas akan seni yang tidak terbatas, yang mencerminkan kembali kemahakuasaan Tuhan, akan semakin besarlah kemungkinannya orang dapat berhasil mencapai kebenaran dan ideal seni ( Barry [et.al.], 1964:24-25).

Sekarang, bagaimana permainan menghidupi itu bisa terjadi dengan berusaha memadatkan cita-cita itu pada ide selanjutnya, penerimaan ide itu, pembentukan fantasi perasaan pada kesan yang diterimanya, hal mana akan tetap menjadi rahasia, karena itu dilaksanakan dalam ketidak sadaran. Di situ kita hanya bisa mengerti itu 'bahwa' demikian dan bukan 'bagaimana' (Fleming, 1979:5).

Bila seorang pelukis atau pematung tertarik hatinya pada keindahan dari suatu bagian alam atau dari suatu gambaran fantasi yang kebetulan timbul, penyair misalnya dari suatu pertemuan dengan suatu bahan yang; puitis, pemusik dari suatu tema musikal yang bersemangat dan bersamaan itu ada perasaan: "Itu harus kamu ujudkan!", demikian memang padanya kehamilan atau penerimaan ide suatu karya seni itu terserap. Karena itu untuk selanjutnya, Driyarkara (1980:10) mengatakan, "Suara estetik yang diterimanya akan "digambarkan" (lukis), atau "dipatungkan" (pahat), atau “di bahasakan” (sastra), atau “disuarakan” (musik).” Mereka mengalami suatu ketegangan yang tinggi pada rasa inginnya, yang berkaitan dengan dorongan 
mencipta. Tetapi mereka umumnya belum tahu akan kehamilan sesaat, dan akhirnya apa yang akan diujudkan dari janin yang hidup itu.

\section{Pertumbuhan}

Pertumbuhan janin yang hidup itu harus kita bayangkan sebagai ide yang semakin kuat menguasai fantasi perasaan, yang makin sempurna membentuk kepribadian manusia di dalamnya. Demikian, ide itu akan mengarah ke pusat yang tersembunyi dalam hidupnya dan pengalaman pribadinya. Seluruh cita-cita yang berorientasi ke pusat itu akan berpengaruh terhadap penetralan kembali keseimbangannya yang telah terganggu. Semua pengalaman yang baru diperolehnya akan menuju ke pusat pengalaman itu, yaitu ke ide (Barry [et.al.], 1964:22 ).

Begitulah janin berkembang, dihidupi oleh pengalaman-pengalaman baru yang selalu berbaur, dan akhirnya tumbuh besar menjadi suatu organ psikis yang terdiri dari banyak bagian, yang menuju ke suatu gambaran fantasi yang makin sempurna menggambarkan serta mencerminkan kepribadian seniman secara resmi di dalamnya.

Pertumbuhan kandungan ide itu berjalan tanpa sadar dalam kegelapan. Seniman hanya mengalami dalam dirinya gejolak fantasi yang kuat, suatu perhatian yang semakin meningkat pada segala sesuatu yang ada sangkut-pautnya dengan ide. Dia merasa ada suatu gangguan dalam yang hebat. Suatu pernyataan yang masih selalu mengganggu keseimbangan, yang merupakan bumbu di dalam, akhirnya dia akan puas dengan perujudan dalamnya. Dia belum melihat secara keseluruhan, bahwa belum ada kesatuan dalam bermacam jenis itu, yang bisa mengungkapkan pribadinya secara sempurna. Oleh karena itu dia mengalami tahap pertumbuhan itu belum lagi merupakan pembebasan keinginan estetis, tetapi merupakan keadaan estetis yang sepenuhnya memaksa (Margolis, 1980:10).

\section{Kemasakan}

Ide telah dikawinkan dengan kepribadian melalui perantaraan fantasi perasaan, semua pengalaman telah disamakan dan telah diorientasikan di situ sebagai pusat pengalaman, dengan begitu keseimbangan yang baru akan tercapai (Tedjoworo, 
2009:45). Ide pandangan dalam karya seni itu telah masak. Sekarang seniman berada pada posisi mempersatukan gambaran fantasinya. Dia berhadapan dengan organ psikis, pandangan dalamnya dipenuhi dengan keinginan estetis yang tinggi. Karena dalam fantasinya dia terangsang hatinya dan diorganisasi alam sekitarnya. Sekarang bertemu lagi pengesahan dirinya, karena itu dia sekarang bebas dengan pandangannya sendiri dan tidak ada lagi hambatan di dalamnya. Pengalaman kemasakan itu berarti puncak dari pada pengalaman perasaan dalam berkarya seni (Margolis, 2012: 356).

Driyarkara (1980:32) telah menyinggung pula tentang pengalaman manusia yang tidak sama hebatnya. Memang, soal hebat tidaknya pengalaman manusia itu tergantung dari bakat dan kemampuan masing-masing, lagi pula itu tergantung pada keadaan konkritnya. Karena itu diketahui juga bahwa manusia itu selalu disibukkan oleh bermacam-macam persoalan, sehingga mungkin sekali mereka itu mengalami saat estetik itu secara dangkal saja.

Tetapi dengan pengalaman kemasakan tadi orang merasa terikat dan bersamaan itu pula ada suatu dorongan yang kuat untuk segera menemukan jalan keluar. Ini berbeda dengan apa yang sebenarnya estetis, tapi tidak untuk orang yang memiliki bakat istimewa mencipta di sini seniman terdesak oleh fantasi ciptanya, untuk segera mengobjektifkan pengalamannya yang mengendap dari luar. Oleh karena itu dia sekarang sadar untuk menekan keadaan dirinya. Maka dari itu mungkin, bahwa gambaran fantasi ciptanya menjadi semakin kuat, langsung menghidupkan, serta reaksi perasaan yang timbul harus dilahirkan dengan gerakgerak ekspresi yang bergairah, kemudian membentuknya melalui perantaraan gambaran fantasi ke dalam suatu ujud (Tedjoworo, 2009:60).

Sekarang gambaran fantasi yang telah masak itu bisa menjadi dorongan ekspresif yang hanya diperintahkan oleh perasaan. Oleh karena itu keikut sertaan akal yang sedang menganalisa dan memberi aba-aba tidak perlu lagi (Fleming, 1979:60 ). Tetapi sekarang karya seni yang kelihatan dalam fantasi sebagai gambar pribadi seniman, merupakan organ yang banyak bagiannya. Itu hanya bisa dilahirkan berupa tindakan secara berangsur-angsur, misalnya: ke arah kesadaran yang jelas, 
serta hubungan masing-masing tindakan itu satu dengan yang lainnya. Jadi itu harus tumbuh dengan baik hingga masak, tetapi itu berjalan secara tidak sadar dan lagi hanya muncul dalam bentuk-bentuk fantasi ke dalam kesadaran. Suatu proses berjalan, dimana akal ikut ambil bagian. Jadi sadar akan arah cita-cita kehendaknya. Itulah sketsa.

\section{Sketsa}

Dalam tahap ini seniman mencari terang dengan bantuan akal seninya, yaitu dengan teknik yang bagaimana dia sekarang harus membentuk karya seni itu, yang dia terima dan telah menjadi masak itu. Dia mencari terang itu dengan sinar akalnya. Hal ini berarti suatu proses penginsyafan. Tetapi bagaimana pun juga seniman tetap merasa dirinya kecil, hatinya kalut, sadar akan kelemahannya, akan keterbatasannya.

Tetapi sketsa itu penting. Penciptaan yang sebenarnya, pembentukannya harus didorong oleh perasaan. Carrol dalam bukunya, Philosophy of Art (1999:54), menyinggung bahwa perasaan itu buta. Apakah itu betul? Hal ini bisa dibuktikan sendiri dari reaksi-reaksi yang timbul dari pengaruh gambaran-gambaran fantasi. Oleh karena itu seniman dalam beberapa hal dalam sketnya telah menarik garis-garis besar, serta membuat celah-celah, dimana dia bisa mengisinya pada saat-perasaan membentuk. Bersamaan dengan itu, dia mempertimbangkan akibat perasaan yang datang dari masing-masing bagian karya seni, yang terlihat dalam fantasi itu satusama lain, Agar di tengah perjalanan menganalisa nanti bisa dicapai suatu keadaan yang seimbang, seperti saat dia mengalami kemasakan gambaran fantasi itu secara sintetis. Dia telah meletakkan dalam beberapa hal 'kerangka' karya seni itu secara telanjang dalam sketsanya.

Sketsa tersebut dalam banyak hal bisa menjadi suatu tindakan dalam yang murni. Dan itu bisa menjadi aturan buat segolongan kecil karya seni. Pada sebuah pantun yang pendek, misalnya, itu bisa ditentukan dengan sepintas kilas akal, yang secara cepat telah mencakup penegasan pikiran. Pada banyak bagian karya seni sebaliknya, sketsa telah ditegaskan ke dalam bahan dasarnya. Pengamata dapat membayangkan ini pada sketsa para: pelukis, pematung, dramawan, dan lain sebagainya. Sketsa-sketsa seperti itu keindahannya seringkali minim, kering, dan 
sederhana saja. Tetapi sketsa-sketsa itu bagaimana pun juga telah menunjukkan garis-garis besar pengaruh perasaan, serta telah membuka tabir bagaimana caranya menuju titik pusat, yaitu 'ide'. 'Karya seni melayang di antara bola yang penuh rahasia dari tanda dan kesan: "Kalau itu hanya merupakan kesan saja akan membuat hati manusia kalut, kalau hanya merupakan tanda raja itu menjadi sesuatu yang mati” (Carrol, 1999:77). Oleh karenanya sket-sket itu sering kali bisa mendukung pengertian yang lebih mendalam dari karya seni, dan proses terjadinya karya seni tersebut.

Sejauh perasaan seniman terlibat pada sketsa itu, maka sudah menjadi kaprah kalau pada semua perbuatan estetis, yang tidak ada kerja samanya rasa tidak akan jadi. Maka dengan bagian-bagian macam itu sampailah sudah sket itu pada tahap akhir yang terpenting proses penciptaan. Akhirnya, manusia masuk pada tahap pembentukan.

\section{Pembentukan}

Dalam proses pembentukan ini meledaklah desakan ekspresi seniman, yang merupakan suatu kejadian kejiwaan yang murni, yaitu pengalaman fantasi seniman. Karena itu harus ditahan dan ditekan pada kesadarannya sekarang, bahwa itu harus digambarkan dalam suatu bahan dasar. Tetapi itu hanya bisa terjadi melalui gerakangerakan badani, yang tidak digerakkan secara langsung oleh akal, tetapi langsung dari perasaan. Hanya karena nafsu perasaan seperti itu telah melahirkan gerakan-gerakan, yang bisa menekan perasaan tersebut, akhirnya menjadikan sebab perasaan itu menggambarkan bayangan-bayangan fantasi. Demikian seperti manusia yang terangsang kuat oleh perasaannya, mencoba melukiskan gambaran rangsangan itu melalui gerak-gerak tangan yang tidak disengaja. Begitulah seniman menggambarkan bentukbentuknya dengan pertolongan dorongan ekspresi gerak-gerak yang merangsang perasaan. "Seperti pada setiap perkembangan, demixian juga yang sama pada masalah seni seperti halnya sikap, suatu permulaan yang dijelaskan sebagai akhir dan suatu akhir yang dijelaskan sebagai permulaan” (Barry, 1964:22-24).

Jadi, manusia bisa membayangkan proses pembentukan itu sebagai berikut. Fantasi adalah pembawa akibat ke arah penciptaan. Begitu hidupnya gambaran 
fantasi itu hingga dapat membawa pribadi seniman untuk menciptakan itu kembali. Itu selalu mengganggu keseimbangan dalam, akhirnya ke luar membawa reaksi perasaan ke arah pembebasan diri, tetapi juga ke arah keterbukaan diri seniman (Barry, 1964:24-34). Dalam usaha membangun kembali keseimbangan serta ekspresi perasaan, keterbukaan diri langgsung di arahkan kegerak-gerak ekspresi melalui rangsangan gambaran fantasi tersebut, sekaligus menggambarkan pribadi seniman dengan resmi. Akal sendiri berada di latar belakang. Boleh dikatakan, tindakantindakan itu telah dilaksanakan sebelumnya dalam sket. Demikianlah sekarang tanpa kerjasama secara langsung dalam proses pembentukan itu, tetapi dengan penuh perencanaan, yang bisa menghasilkan bentuk kesatuan, dan di dalam kesatuan itulah pribadi seniman diekspresikan.

Hal tersebut telah dijelaskan di depan, bahwa dalam kegiatan berfantasi, kesan seluruh tujuan cita-cita pribadi seniman secara harmonis sempurna ditekankan dalam tindakan yang reaktif. Karena pada proses pembentukan, kedua kekuatan itu telah menimbulkan pengalaman pahit, maka maklumlah, bahwa seluruh tujuan citacita itu, juga seluruh pribadi seniman dengan resmi digambarkan secara langsung.

Itu mengenai hal yang tidak diketahui pada pembentukan, tindakan-tindakan yang dipertimbangknn. Itu memang telah dikerjakan terlebih dulu dalam sketsa. Seniman lebih banyak membentuknya ke luar dari kegelapan, yaitu dari gaya hidupnya yang gelap, bersamaan itu pula belajar dari gambaran fantasi yang dikemudikan oleh cita-cita perasaan yang sesuai baginya. Karena itu dia tidak bisa melaporkan, bagaimana sebenarnya dia telah menghasilkan karya seni. Dia hanya bisa berkata: "Saya harus berbuat demikian, saya telah merasa digiring ke sana. Oleh karena itu tak pernah bisa menyusun sesuatu aturan bagaimana suatu karya seni harus diciptakan" (Wollhem, 1980:56). Filsafat seni di sini pada umumnya tidak bisa berbuat lebih lanjut, tetapi hanya berusaha menemukan pengesahannya secara umum (Fleming, 1979:34).

Karena hal tersebut secara umum telah menguasai manusia, maka sudah semestinya berlaku juga bagi setiap seniman. Oleh karena itu hal tersebut harus 
berlaku juga untuk setiap karya seni. Pengesahan umum itu bisa kita kenal atas dasar pelaksanaan sampai sekarang ini.

Cobalah perhatikan, dalam pribadi manusia terletak suatu dasar pembentukan secara keseluruhan, yang bagi kita merupakan prinsip pembentukan yang bersifat apriori, yang tiada lain adalah suatu kesan pengesahan mengenai pembeberan dirinya,yang mendorong ke arah ekspresi diri. Karya seni tidak hanya sebagai keseluruhan saja, ia ada dalam bagian-bagiannya juga yang merupakan kesan kehidupan jiwa serta dunianya, dari manusia dan semua: selain itu bergerak sebagai pecahan dari sebuah figur yang antik kepada kita tidak kepada yang terdalam (Fleming, 1979:160)

Pada setiap perbuatan manusia sampailah ke suatu nilai estetis yang paling murni dan paling sempurna, terutama dalam hal penciptaan seni melalui perantaraan fantasi perasaan. Pada pekerjaan itu pribadi seniman sebagai keseluruhan selalu terlibat. Dengan begitu ciptaan seni berarti: kesan pengalaman dalam kesadaran akan alam sekelilingnya, yang dituangkan melalui perantaraan bahan dasar yang dipergunakannya. Di dalam proses pembentukan, seniman menggambarkan organorgan kejiwaan yang tumbuh sampai masak dalam gambaran fantasi melalui perintah perasaan menjadi gerak-gerak ekspresi. Di dalam gambaran itu, di dalam karya seni, harus ditegaskan pengesahan pribadi seniman. Karena tujuan cita-cita sekarang lebih banyak disatukan, yaitu kesatuan dari banyak hal, maka pengesahan umum berarti bagi setiap orang, jadi berlaku juga bagi setiap seniman. Kita harus bisa menemukan kembali pengesahan umum tersebut dalam setiap karya seni, yang juga merupakan kesatuan dari banyak hal itu. Di situ tujuan cita-cita sama seperti yang telah didengar, pada hakikinya telah dinyatakan oleh setiap orang sebagai pembebasan diri dan pembebasan cita-citanya sendiri. Maka demikian manusia akan menemukan kembali cita-cita itu secara simbolis dalam setiap karya seni (Saini, 2001:44).

Mengenai pengesahan umum tersebut berlaku juga untuk semua bidang seni, telah disusun suatu pengesahan khusus yang berlainan untuk masing-masing bidang seni. Teori seni dalam hal ini telah mendapat tugas khusus untuk menyelidiki kemungkinan-kemungkinannya. Pengesahan khusus tersebut merupakan penyerahan 
diri atas kerjasama pengesahan umum material, di mana seniman menggambarkan pengalamannya, dan organ tertentu di mana material tersebut dipergunakan. Mengenai pengesahan khusus itu akhirnya disusun pengesahan yang bersifat individu sebagai menara gading, di dalamnya tercermin individu seniman. Hal itu tidak bisa disalurkan'masuk keteori umum lagi, tetapi sebagai sesuatu yang terakhir, dapat ditentukan hanya sebagai perasaan ugahari. Penentuan tersebut bisa menjadi suatu saran monografis pembahasan seni (Saini, 2001:60).

Setiap karya seni mengambil bagian dari ketiga pengesahan tersebut. Pada masing-masing tinggallah suatu sisa yang tidak bisa dimengerti oleh akal, tetapi hanya bisa ditangkap oleh perasaan saja. Di lain pihak dikatakan bahwa itu hanya bisa dialami oleh perasaan saja, individu yang murni pada hakekatnya adalah karya seni itu sendiri.

Filsafat seni umum sebenarnya telah memecahkan persoalan yang relatif sederhana ini: yaitu dengan menentukan pengesahan umum beserta kesimpulankesimpulan penyerahan dirinya. Apakah dia akan mampu berbuat lebih, melebihi batas benda yang diselipkan? Inilah tugas suatu seni, untuk mendobrak kesempitan dan meninggalkan rasa takut yang tak terhingga serta sekaligus membukakan jendela akalnya untuk mengidam-idamkan yang tak terbatas (Fleming, 1979:87; Saini, 2001:67).

Bagaimana sekarang masalahnya mengembangkan kesimpulan-kesimpulan semacam itu? Kita di sini akan menemukan, bahwa dari kepastian di atas, penciptaan seni terpengaruh oleh pengesahan umum, artinya bahwa teori umum penciptaan seni samasekali berpangkal dengan sendirinya pada kejernihan dan pada kejelasan pengertian orang tentang seni. Di situ nampak pertumbuhan yang sangat subur secara genetis.

Kalau manusia tahu, pengesahan umum yang mana yang pegang peranan penting dalam penciptaan seni ini, bersama itu pula kita tahu, pengesahan umum yang mana yang ditekankan dalam karya seni, artinya kita beruntung situ pandangan dalam kejadian seni . 


\section{KESIMPULAN}

Seni sebagai realitas estetis. Keindahannya memancarkan suatu kreativitas yang luar biasa. Ia berada dalam lingkungan di mana ia dilahirkan, namun juga tak jarang ia berada di luar lingkungan di mana ia dilahirkan. Realitas estetis yang ditampilkan sebuah karya seni sebagai sebuah keutuhan, baik keutuhan material maupun formal.

Karya seni yang hadir dalam realitas merupakan karya manusia (seniman). Proses dalam suatu karya seni lebih menitikberatkan pada dimensi estetis dan kreatif seorang seniman. Namun, proses terjadinya karya seni tidaklah sesederhana seperti hanya melihat karya seni yang sudah jadi. Dalam prosesnya, seorang seniman berkontemplasi estetis hingga mampu mendeformasi objek material ke dalam bentuk suatu karya seni. Proses inilah yang dapat dilihat sebagai salah satu bentuk kreativitas seniman. Dari kata “proses” tersebut kiranya perlu direnungkan lagi katakata seorang Filsuf Inggris, Alfred North Whitehead (1861-1947), yang menuliskan tentang Filsafat Proses:

Realitas bukanlah sesuatu yang statis, tetapi terus bergerak dan berubah dalam suatu proses yang tak kunjung berhenti. Dalam prinsip realtivitas, "yang banyak" yaitu satuan-satuan aktual yang sudah lengkap, selalu terlibat dalam proses pembentukan "yang satu", yakni satuan aktual baru yang membentuk dan mencipta diri. Seluruh alam terus terlibat dalam proses transmisi maupun kenkresi (Ali Mudhofir, 2001:535). 


\section{DAFTAR PUSTAKA}

Ali Mudhofir, 2001, Kamus Filsuf Barat, Yogyakarta: Pustaka Pelajar.

Barry, Sir Gerald, (et.al.), 1964, The Art: Man's Creative Imagination, New York: Doubleday and Company Inc.

Carrol, Noel, 1999, Philosophy of Art: A Contemporary Introduction, London - New York: Routledge.

Driyarkara, N., 1980, Driyarkara tentang kebudayaan, Yogyakarta: Penerbit Yayasan Kanisius. 1978, Filsafat Manusia, Yogyakarta:Penerbit Yayasan Kanisius.

Fleming, William, 1979, Art and Ideas, New York: Rinehart and Winston.

Margolis, Joseph, Pengantar ke dalam Probelem-problem Filsafat, diterjemahkan oleh Theophilius J. Riyanto. Yogyakarta: Kanisius. 1980, Art and Philosophy: Conceptual Issues in Aesthetics, Great Britain: The Harvester Press Ltd.

Saini K.M., 2001, Taksonomi Seni, Bandung: STSI Press.

Tedjojiwo, H., 2009, Imanji dan Imajinasi: Suatu Telaah Filsafat Postmodern, Yogyakarta: Kanisius.

Wollheim, Richard, 1980, Art and Its Object, New York: Cambridge University Press. 